\title{
CONSUMPTION OF FRUIT AND VEGETABLE WITH RISK OF OBESITY IN SCHOOL-AGE CHILDREN
}

\author{
Agnes Sevelina Anggraeni, Tintin Sukartini, Kristiawati \\ Faculty of Nursing Universitas Airlangga \\ Kampus C Jl.Mulyorejo Surabaya 60115, Telp. 0315913754 \\ Email: agnessevelina@ymail.com
}

\begin{abstract}
Introduction: The problem of obesity in children aged 5-12 years in Indonesia is still high, East Java is one of the provinces that have higher prevalence of obesity than the national average (Riskesdas 2013). Consumption of fruit and vegetables affects the level of obesity's risk, but nowadays fruit and vegetable consumption in school-age children are low. This study was aimed to determine the correlation between consumption patterns of fruits and vegetables with the risk of obesity in school-age children in Ketabang I Surabaya elementary school. Method: This research uses the descriptive correlation method with cross sectional approach. The population of this research is students in grade 4 and 5. Purposive sampling technique used to select 69 respondents as samples. The independent variable in this study is the consumption pattern of fruit and vegetable, while the dependent variable is the risk of obesity. The data were analyzed with chi-square test. Result: The results of this research showed that most of respondents consume less fruit and vegetable (52\%). The number of respondents who are obese is $20 \%$, while the number of respondents who have high risk is $13 \%$. Statistical analysis showed that the consumption pattern of fruits and vegetables has a correlation with the risk of obesity $(p=0.009)$. Discussion: There was a significant relationship between the consumption patterns of fruit and vegetables with risk of obesity in school-age children in Ketabang I Surabaya elementary school. Further studies should examine the appropriate interventions to overcome the problem of obesity in school-age children.
\end{abstract}

Keywords: consumption pattern of fruit and vegetables, risk of obesity, school-age children.

\section{INTRODUCTION}

Obesity in children is a serious medical problem that affects children in the developed and developing countries because obesity potentially cause comorbidities and increased the risk of some chronic diseases (Vash, 2015). The prevalence of overweight and obesity in children and adult increased at the end of the 20th century spread evenly in all over the countries in the world (Bray \& Bouchard, 2014). Nowadays, children tended to prefer fast food with the reason that it feels good, and a tendency consumption of fruit and vegetable is low that can cause fatness on child, whereas on the childhood period is really important to consume fruits and vegetables because it can help the children to apply a healthy food consumption pattern to controls and organizes weight (Dewi 2013). Fruits and vegetables can minimize the risks of obesity in children, because fruits and vegetables can burn fat without makes many calories (CDC 2011).

In Indonesia, problems of fatness in school age children (5 to 12 years) are still high $(18.8 \%)$, consisting of overweight $10.8 \%$ and obese $8.8 \%$. East Nusa Tenggara have the lowest prevalence of overweight $(8.7 \%)$ and the highest prevalence is in Jakarta $(30,1 \%)$. There are 15 provinces with prevalence of obesity that above the national average, that provinces are Central Kalimantan, East Java, Banten, East Kalimantan, Bali, West Kalimantan, North Sumatra, Riau, Jambi, Papua, Bengkulu, Bangka Belitung, Lampung and Jakarta (Riskesdas, 2013). Research by nutrition institutions survey and National Health about prevalence of obesity in 2008 to the children in primary schools and play group in ten cities in Indonesia consecutively from the highest are Jakarta (25\%), Semarang $(24,3 \%)$, Medan (17.75\%), Denpasar (15.7\%), Surabaya (13.4\%), Palembang (12.2\%), Padang (7.1\%), Manado (5.3\%), Yogyakarta (4\%) and Solo $(2.1 \%)$. Mean prevalence of overweight in ten cities has reached $12.7 \%$ (Wahyu, 2009).

Obesity can cause the various diseases, such as heart disease, hypertension, diabetes type 2, metabolic syndrome, hipercolesterol, asthma, sleep disorder, orthopedic complication, and mental disorder (Paxon, 2010). Obesity also has adverse indirect effects to the decline in cognitive function most likely due to the impact of illnesses that suffered by the obese children (diabetes, obstructive sleep apnea syndrome (OSAS), problems of respiration), problem related to psychosocial (inferiority, self isolation, and depression) and also social maturity (Wendt, 2009). 
Researcher did a survey to 586 students in SDN Ketabang I Surabaya and obtained the results of $3.75 \%$ high risk to obesity and 14.6 $\%$ are obese. The results of the interviews from 20 students known that $25 \%$ did not like to eat vegetable, $5 \%$ did not like to eat fruit, and $5 \%$ did not like to eat fruits and vegetables. Among $25 \%$ of children that does not like ate vegetables, two children are having nutritional status of belonging to the obesity, whereas 18 students who have been were interviewed has low risk category. The reason of the students who was not like to eat fruit or a vegetable is because it has bad taste.

Based on that background, the purpose of this study is to investigate the correlation between consumption pattern of fruits and vegetables with the risk of obesity in schoolage children in Ketabang I Surabaya elementary school.

\section{METHOD}

This research using descriptive correlational design with cross sectional approach, where the data was taken in the same time. This method chosen to define the relationship between consumption patterns of fruits and vegetables with risk of obesity in school age children.

This study was conducted in Ketabang I Surabaya elementary school. The affordable population on this research are the students from $4^{\text {th }}$ and $5^{\text {th }}$ grade in Ketabang I Surabaya elementary school as much as 218 students. The students from $4^{\text {th }}$ and $5^{\text {th }}$ grade were chosen to be samples because the obesity prevalence from that grade is the highest among al of the grades in Ketabang I Surabaya elementary school. The number of respondents that needed as samples for the research is 75 respondents. The number of the respondents were taken from the classroom with the highest prevalence of risk to obesity and obesity among $4^{\text {th }}$ and $5^{\text {th }}$ grade in Ketabang I Surabaya elementary school. Students who selected to be sample are 29 students from $4 \mathrm{~b}$ class, 8 students from $4 \mathrm{a}$ class, and 38 students from $5 b$ class.

Sampling techniques that used in this research is purposive sampling. To minimize the bias, the inclusion criterias were: 1) $4^{\text {th }}$ and $5^{\text {th }}$ grade of Ketabang I Surabaya elementary school. 2) Students that able to understand and answer the written questions. 3) Students who has been approved by their parents / teachers to be respondents in this study. The exclusion criterias are: 1) students who have allergic to particular fruit and vegetables. 2) students who is sick while the data being collected

The independent variable in this research is consumption patterns of fruits and vegetables, while the dependent variable in this research was risk of obesity that known from the BMI (Body Mass Index) according to age. The instrument that used in this research is semiquantitative food frequency questionnaire that adapted and modified from NHANES (2005-2006), the eating pattern questionnaire used to obtain data relating consumption patterns fruits and vegetables qualitatively, adapted and modified from Eating Pattern Questionnaire Prochildren (2003) for measuring consumption patterns of fruits and vegetables over a week, and WHO Anthroplus to know the BMI of the children according to age.

Primary data that gathered through questionnaire such as identity, attitude and consumption of fruits and vegetables. The data about consumption frequency of fruits and vegetables obtained through Food Frequency Questionnaire. The data about nutritional status were known through measurement of the height and weight, and calculation of body mass index according to age. Secondary data that needed were description of the school like the number of the students, the names of students, class, sex, and school overview that obtained from the administration staff in Ketabang I Surabaya elementary school.

Data collection was done by conducting anthropometry measurement, structured interview using food frequency questionnaire, and deploy eating pattern questionnaire to the students. This activity was conducted alternately from one class to another class. The researcher explain about the research to the prospective respondents, provides informed consent to the teacher of the respondents. The teacher considered to be agree that the student become the respondents of this research after signed the informed consent. After filling the informed consent, researcher doing the measurement of height and weight, body mass index according to age calculated by using application WHO Anthroplus. After that researchers conducted interviews on child to know the frequency and the amount of consumption of fruits and vegetables by using 
semiquantitative food frequency questionnaire. The interviews were conducted alternately on every respondents. At the time of interview researchers used simple daily conversation so easy to understand by the respondents. The time that needed to interview every student is about 5-10 minutes.

Next, researchers share a questionnaire that contained about risk of obesity analysis on children and consumption patterns of fruits and vegetables, respondents were accompanied by the researchers while filling the questionnaire. The data that obtained from the answer of the questionnaire during was put into tabulation then analyzed use Chi Square statistical tests. After the data collected processed, so the next stage is to do the interpretation of the results.

\section{RESULT}

At Ketabang I Surabaya elementary school there is a canteen that sells foods for the students, but the kind of food that sold there contain high calories. In front of the schools gate there are also many food retailer, kind of food that sold also contain high calories and unhygienic. This situation makes the students had no choice to buy a healthy and nourishing food at school because of the lack of availability of nutritious food at school, eventhough school-age children need a balanced nutrition to support optimal development and growth.

Table 1. Distribution of demographic characteristic of the respondents

\begin{tabular}{|c|c|c|c|c|}
\hline No. & $\begin{array}{c}\text { Demographic } \\
\text { Data }\end{array}$ & Category & f & $\%$ \\
\hline \multirow{3}{*}{1} & \multirow{2}{*}{ Sex } & Male & 33 & $48 \%$ \\
\hline & & Female & 36 & $52 \%$ \\
\hline & Tota & & 69 & $100 \%$ \\
\hline \multirow{4}{*}{2} & \multirow{3}{*}{ Age } & 10 years & 17 & $25 \%$ \\
\hline & & 11 years & 31 & $45 \%$ \\
\hline & & 12 years & 21 & $30 \%$ \\
\hline & \multicolumn{2}{|c|}{ Total } & 69 & $100 \%$ \\
\hline
\end{tabular}

The number of respondents based on sex are 33 male students (48\%) and 36 female students $(52 \%)$. Respondents in this research is aged 10-12 years, and the respondents who was 11 years old has the most frequency, 31 students $(45 \%)$.
Table 2. Distribution of the respondents based on fruits and vegetables consumption

\begin{tabular}{cccc}
\hline No. & $\begin{array}{c}\text { Consumption of fruits } \\
\text { and vegetables }\end{array}$ & f & $\%$ \\
\hline 1 & Less & 36 & $52 \%$ \\
2 & Good & 33 & $48 \%$ \\
& Total & 69 & $100 \%$ \\
\hline
\end{tabular}

Consumption of fruits and vegetables are categorized as good if the number of fruits and vegetables consumed are $\geq 400$ grams per day. Consumption of fruits and vegetables are categorized as less if the number of fruits and vegetables consumed are <400 grams per day (WHO 2007). The consumption of fruits and vegetables was calculated by using semiquantitative food frequency questionnaire, from 69 respondents, there are $52 \%$ consumed less fruits and vegetables, and $48 \%$ have good consumption of fruit and vegetables.

Tabel 3. Distribution of the respondents based on risk of obesity

\begin{tabular}{clcc}
\hline No & Risk of Obesity & f & \% \\
\hline 1 & Low risk & 46 & $67 \%$ \\
2 & High risk & 9 & $13 \%$ \\
3 & Obesity & 14 & $20 \%$ \\
& Total & 69 & $100 \%$ \\
\hline
\end{tabular}

Most of the respondents included in a low risk category $(67 \%)$, followed by obesity (20\%), and the lowest is high risk category $(13 \%)$.

In table 4 can be seen that consumption of fruit and vegetable in the good category be greater among respondents who have low risk to obesity, namely $40.6 \%$. In the majority of respondents with high risk to obesity show consumption of fruits and vegetables is low, namely $10.1 \%$. Among the respondents who was obese consumption of fruits and vegetables that categorized as less as many as $15.9 \%$. The results of statistical tests shows the $p$ value is 0.009 , so it can be said that there was a meaningful relationship between consumption patterns of fruits and vegetables with the risk of obesity. 
Tabel 4. Coreelation Fruits and Vegetables Consumption with Risk of Obesity using Chi Square test

\begin{tabular}{|c|c|c|c|c|c|c|c|}
\hline \multirow{3}{*}{$\begin{array}{l}\text { Fruits \& Vegetables } \\
\text { Consumption }\end{array}$} & \multicolumn{6}{|c|}{ Risk of Obesity } & \multirow{3}{*}{$\begin{array}{c}\mathbf{P} \\
\text { value }\end{array}$} \\
\hline & \multicolumn{2}{|c|}{ Low risk } & \multicolumn{2}{|c|}{ High risk } & \multicolumn{2}{|c|}{ Obesity } & \\
\hline & $\mathbf{f}$ & $\%$ & f & $\%$ & $\mathbf{f}$ & $\%$ & \\
\hline Less & 18 & 26.1 & 7 & 10.1 & 11 & 15.9 & 0.009 \\
\hline Good & 28 & 40.6 & 2 & 2.9 & 3 & 4.3 & \\
\hline Total & 46 & 66.7 & 9 & 13 & 14 & 20.3 & \\
\hline
\end{tabular}

\section{DISCUSSION}

The mean of daily fruits and vegetables consumption among students in Ketabang I Surabaya is enough to fulfill suggestion from the WHO namely $\geq 400$ grams per day, but if considered from the individual consumption, the majority of respondents consumed less fruits and vegetables. Lack of fruits and vegetables consumption in children can be influenced by many factors, one of them is preference to fruits and vegetables. In this research, preference of fruits and vegetables means pleasure of the respondents towards fruits and vegetables. Respondents's preference of fruits and vegetables most affected by a taste. Negative preference of vegetable quite high compared with negative preference of fruit. The respondents that like all fruits and vegetables said that their parents provide fruits and vegetables everyday at home, while the respondents that does not like fruits and vegetables did not specify the reason why they do not love fruits and vegetable, they only reason that fruits and vegetables have a bad taste.

The research's results show that students in Ketabang I Surabaya elementary school mostly love fruit than vegetable. Researchers thought that taste and the availability of fruit at home impact on the consumption patterns of fruit and vegetable. This is corresponse with the results of the study conducted by Kronel (2011) that concludes that the main reason for the children and teenage dislike to consume fruits and vegetables is the taste, also the availability and access of fruits and vegetables at home affect consumption patterns of fruits and vegetables.

Table 3 shows that the respondents with the low risk has the highest frequency, followed by obesity, and the high risk has the lowest frequency. There were few respondents with high risk and obesity, nevertheless attention must be given to them because it can be bad for health. The impact that appear as the of effect obesity are heart disease, hypertension, diabetes type 2, metabolic syndrome, hipercolesterol, asthma, sleep disorder, orthopedic complication, and mental disorder (Paxon, 2010). The incidence of high risk to obesity in Ketabang I Surabaya elementary school has the potential to raise incidence obesity if it is not done by appropriate treatment and precautionary.

Data from the research results known that there is meaningful relations between consumption patterns of fruits and vegetables with the risk of obesity in school age children in Ketabang I Surabaya elementary school. This result is in accordance with the research of Sartika (2011) which indicates the presence of meaningful relations between consumption patterns of fruits and vegetables with risk of obesity on 5-15 years children in Indonesia. The same with the research of Nuraeni (2013) indicates that school age children who obese are rarely and consume less fruits and vegetables compared with the child who is not obesity in Yogyakarta and Bantul. Children that rarely and consume less fruits and vegetables can increase the risk of obesity.

Fruits and vegetables are the food that contain low density of energy that can manage an ideal weight. Fruits and vegetables are the source of various essential nutrient, as potassium, vitamin c, folic acid, fiber, and many phytochemical (CDC, 2008). Fruits and vegetables also content high amounts of fibers. Fibers play an important role in the process of digestion. Fibers fill the place in gaster and give satiety and decrease intraluminal pressure of the intestines. Soluble fibers can slow down the intestines absorption of fat and glucose (Mustofa, 2015). Water-soluble fibers as pectin and several hemiselulose having the ability to hold water and may form a viscous liquid in the gastrointestine tract, so that the high fibers foods having longer time to digest in the stomach. Then fibers will pull the water and give satiety longer so that can prevent to consuming more food. Food that contain higher raw fiber usually contain low calories, low sugar, and low fat that can help to reduce 
the risk of obesity (Ichsan et al., 2015). This is in accordance with the results of the study of Santoso (2011) explained that water-soluble fibers can control weight or overweight (obesity).

The enhancement in public consumption of fruits and vegetables inversely proportional to the changes in weight, the results of substitution examination sensitivity analysis suggest to replace $5 \%$ calories over the other food to $5 \%$ calories over the fruit or vegetables (Bertola et al., 2015). Replacing high density foods ith low density food in the same amount can produce lower calories, while in the same amount of calories a person can consume more low density food compared with high density food (HSS, 2010). It can be concluded that by consume more fruits and vegetables, risks to be obese will be lower.

The research results that shown in table 4 can be known that the respondents who consume less fruits and vegetables mostly having low risk to obesity. Consumption patterns of fruits and vegetables are not the only cause of obesity in school-age children, but there are various factors that cause obesity. This is also expressed in the results of the study of Sartika (2011) who showed that risk factors of obesity in children aged 5-15 years in Indonesia are characteristic of the child, smoking habit and sports, consumption of fruits and vegetables habits, intake of energy and protein, and the history of obesity parents. According to the Ministry of Health (2012) the main cause of fatness and obesity is environmental factors of the imbalance between food consumption pattern, eating behavior, and physical activity. Bad eating pattern as consume large portions (more than need), high-energy food, high fat, high carbohydrates, and low fiber is the main cause of the fatness and obesity. The research of Guo (2013) said that a short duration of sleep, passing breakfast, and parents who obese are the risk factors of obesity in school age children. Factors that related with the occurrence of obesity are consumption of high calories food that increased the risk to be overweight, consumption of sweet snacks, less physical activity, and spare time that often used to watch television and playing video games (Aballa, 2010). The research result of school age children in Bangladesh explained that the factors that related to obesity in school age children is the obesity history of the parents, less physical activities at home, and high sedentary activities (Zaman \& Ahmed, 2013). Some factors that can cause obesity in school age children are biologic factors and genetic, physical factors include activity pattern and diet, environment factors including social, economy, culture, and physic (Solomon et al. , 2014).

\section{CONCLUSION}

The respondents in Ketabang I Surabaya elementary school partially consumed fruits and vegetables less than the recommendation from WHO, $\geq 400$ gram per day. The majority of respondents in Ketabang I Surabaya elementary school has low risk towards obesity. Consumption pattern of fruits and vegetables related to the risk of obesity in school age children. Fruits and vegetables that contains fibers can help to maintain weight.

The school is expected to supply fruits and vegetables in school by selling foods and drinks in the canteen. The school also can held a program to eat fruits and vegetables at certain event to motivate the students on consuming fruits and vegetables. Parents can introduce various kind of fruits and vegetabless to children since young age. Parents should also provide fruits and vegetables at home everyday to support the increasement of fruits and vegetables consumption in children. Nurse can do routine examination to monitor nutrition status of the children trough health unit in school. The nurse are expected to give education towards the students and parents, and informed about the recommendation of fruits and vegetables consumption. Further studies should examine the appropriate interventions to overcome the problem of obesity in school-age children.

\section{REFERENCES}

Aballa, L.A., 2010. Prevalence and Risks Factors for Obesity Among School Aged Children In Nairobi Province, Kenya. Kenyatta University.

Bertola, M. et al., 2015. Changes in Intake of Fruits and Vegetables and Weight Change in United States Men and Women Followed for Up to 24 Years: Analysis from Three Prospective Cohort Studies. Journal PLOS Medicine.

Bray, G.A. \& Bouchard, C., 2014. Handbook of Obesity, Boca Raton: CRC Press. 
CDC, 2011. Strategies to Prevent Obesity and Other Chronic Diseases, Atlanta: Departement of Health and Human Service.

Dewi, Yessica, 2013. Studi deskriptif: Persepsi dan Perilaku Makan Buah dan Sayuran pada Anak Obesitas dan Orang Tua, Volume 2 Nomor 1 : Calyptra

Guo, X. et al., 2013. Prevalence and Risk Factors of Being Overweight or Obese among Children and Adolescents in Northeast China. International Pediatric Research Foundation, 74(4), pp.443449.

HSS, 2010. Obesity Facts: Fruit and Vegetable Intake in Alaska. Alaska Division of Public Health.

Ichsan, B., Wibowo, B.H. \& Sidiq, M.N., 2015. Penyuluhan Pentingnya Sayuran bagi Anak-Anak di TK Aisyiyah Kwadungan, Trowangsan, Malangjiwan, Colomandu, Karanganyar, Jawa Tengah. Warta, 18, pp.29-35.

Kemenkes, 2012. Pencegahan dan Penanggulangan Kegemukan dan Obesitas pada Anak Sekolah, Jakarta: Kementrian Kesehatan RI.

Kronel, R. et al., 2011. Determinants of Fruit and Vegetable Consumption among Children and Adolescents: A Review of Literature. Part II: Qualitative Study. International Journal of Behavioral Nutrition and Physical Activity, 8(112).

Mustofa, S., 2015. Manfaat Serat Bagi Kesehatan. Biokimia Kedokteran. Available at: http://staff.unila.ac.id/syazilimustofa/201 5/03/26/manfaat-serat-bagi-kesehatan/.

Nuraeni, I., 2013. Perbedaan Konsumsi Buah dan Sayur Pada Anak Sekolah Dasar yang Obes dan Tidak Obes. Ejournal Almaata, 1(2).

Paxon, Christina., 2010. Childhood Obesity.New Jersey : Princeton - Brookings

Riset Kesehatan Dasar., 2013, Riset Kesehatan dasar, Jakarta : Badan Litbangkes Depkes RI.

Santoso, A., 2011. Serat Pangan (Dietary Fiber) dan Manfaatnya bagi Kesehatan. Magistra, 75, pp.35-40.

Sartika, R.A.D., 2011. Faktor Risiko Obesitas pada Anak 5-15 Tahun di Indonesia. Jurnal Makara

Kesehatan, 15, pp.37-43.

Solomon et al., 2014. Pediatric Skills for Occupational Therapy Assistants, Philadelphia: Elsevier Mosby.

Vash, P. D., 2015. The Childhood Obesity Epidemic, (p. xvii), Oakville: Apple Academic Press.

Wahyu, G.G., 2009. Obesitas pada Anak, Jakarta: Bfirst.

Wendt, M.H.D., 2009. Economic, Environmental, and Endowment Effects on Childhood Obesity and School Performance, Tesis: University of Minnesota.

Zaman, S. \& Ahmed, T., 2013. Risk Factors Associated with Overweight and Obesity Among Urban School Children and Adolescents in Bangladesh: A CaseControl Study. BMC Pediatrics. 